University of Nebraska - Lincoln

DigitalCommons@University of Nebraska - Lincoln

1994

\title{
Serologic and Genetic Identification of Peromyscus maniculatus as the Primary Rodent Reservoir for a New Hantavirus in the Southwestern United States
}

James E. Childs

Centers for Disease Control and Prevention, Atlanta, james.childs@yale.edu

Thomas G. Ksiazek

Christina F. Spiropoulou

John W. Krebs

Sergey Morzunov

See next page for additional authors

Follow this and additional works at: https://digitalcommons.unl.edu/zoonoticspub

Part of the Veterinary Infectious Diseases Commons

Childs, James E.; Ksiazek, Thomas G.; Spiropoulou, Christina F.; Krebs, John W.; Morzunov, Sergey; Maupin, Gary O.; Gage, Kenneth L.; Rollin, Pierre E.; Sarisky, John; Enscore, Russell E.; Frey, Jennifer K.;

Peters, C. J.; and Nichol, Stuart T., "Serologic and Genetic Identification of Peromyscus maniculatus as the Primary Rodent Reservoir for a New Hantavirus in the Southwestern United States" (1994). Other Publications in Zoonotics and Wildlife Disease. 74.

https://digitalcommons.unl.edu/zoonoticspub/74

This Article is brought to you for free and open access by the Wildlife Disease and Zoonotics at DigitalCommons@University of Nebraska - Lincoln. It has been accepted for inclusion in Other Publications in Zoonotics and Wildlife Disease by an authorized administrator of DigitalCommons@University of Nebraska - Lincoln. 
Authors

James E. Childs, Thomas G. Ksiazek, Christina F. Spiropoulou, John W. Krebs, Sergey Morzunov, Gary O. Maupin, Kenneth L. Gage, Pierre E. Rollin, John Sarisky, Russell E. Enscore, Jennifer K. Frey, C. J. Peters, and Stuart T. Nichol 


\title{
Serologic and Genetic Identification of Peromyscus maniculatus as the Primary Rodent Reservoir for a New Hantavirus in the Southwestern United States
}

\author{
James E. Childs, Thomas G. Ksiazek, \\ Christina F. Spiropoulou, John W. Krebs, \\ Sergey Morzunov, Gary O. Maupin, Kenneth L. Gage, \\ Pierre E. Rollin, John Sarisky, Russell E. Enscore, \\ Jennifer K. Frey, C. J. Peters, and Stuart T. Nichol
}

Viral and Rickettsial Zoonoses and Special Pathogens Branches, Division
of Viral and Rickettsial Diseases, Centers for Disease Control and
Prevention, Atlanta, Georgia; Medical Entomology/Ecology Branch and
Bacterial Zoonoses Branch, Division of Vector-Borne Infectious Diseases,
Centers for Disease Control and Prevention, Fort Collins, Colorado;
Navajo Area Indian Health Service, Office of Environmental Health and
Engineering, Window Rock, Arizona; Department of Biology, University of New Mexico, Albuquerque

\begin{abstract}
An outbreak of hantavirus pulmonary syndrome (HPS) in the southwestern United States was etiologically linked to a newly recognized hantavirus. Knowledge that hantaviruses are maintained in rodent reservoirs stimulated a field and laboratory investigation of 1696 small mammals of 31 species. The most commonly captured rodent, the deer mouse (Peromyscus maniculatus), had the highest antibody prevalence (30\%) to four hantavirus antigens. Antibody also was detected in 10 other species of rodent and in 1 species of rabbit. Reverse transcriptase-polymerase chain reaction (RT-PCR) products of hantavirus from rodent tissues were indistinguishable from those from human HPS patients. More than $96 \%$ of the seropositive $P$. maniculatus were positive by RT-PCR, suggesting chronic infection. Antibody prevalences were similar among $\boldsymbol{P}$. maniculatus trapped from Arizona (33\%), New Mexico (29\%), and Colorado (29\%). The numeric dominance of $P$. maniculatus, the high prevalence of antibody, and the RT-PCR findings implicate this species as the primary rodent reservoir for a new hantavirus in the southwestern United States.
\end{abstract}

In May 1993 an outbreak of an unexplained acute respiratory illness was recognized in the southwestern United States [1-3]. Serologic studies of human cases implicated a hantavirus, and reverse transcriptase-polymerase chain reaction (RT-PCR) analyses of viral RNA sequences derived from patient and rodent tissues indicated that an unknown hantavirus was responsible $[2,4]$. This virus, not yet isolated but referred to herein as the hantavirus pulmonary syndrome (HPS) virus, was shown by genetic sequence analysis of a 241-bp piece of the G2 gene to be related to Prospect Hill virus (PHV) [4], a hantavirus isolated from the indigenous

\footnotetext{
Received 27 October 1993; revised 12 January 1994.
}

Presented in part: First International Congress of Vector Ecology, October 1993, San Diego (paper 60); 33rd Interscience Conference on Antimicrobial Agents and Chemotherapy, October 1993, New Orleans; and (sponsored by American Committee on Arbovirology) American Society of Tropical Medicine and Hygiene annual meeting, November 1993, Atlanta (paper S93).

The opinions expressed here are those of the authors and do not necessarily reflect the views of the Indian Health Service.

Grant support: US Department of Agriculture Animal Molecular Biology National Research Initiative grant (90-37266-5473) through University of Nevada, Reno (C.F.S. and S.M.)

Reprints or correspondence: Dr. James E. Childs, Viral \& Rickettsial Zoonoses Branch, CDC, MS-G13, 1600 Clifton Rd., Atlanta, GA 30333.

The Journal of Infectious Diseases 1994;169:1271-80 (C) 1994 by The University of Chicago. All rights reserved. 0022-1899/94/6906-0012\$01.00
North American meadow vole, Microtus pennsylvanicus [5]. Antibodies reactive with PHV have been found in humans in the United States $[6,7]$ and infection appears widespread in meadow voles [8-10], but this virus has not been associated with any human disease.

Hantaviruses are trisegmented, negative-strand RNA viruses that are maintained in nature in rodent reservoirs [11]. Each of the four best-characterized serotypes of hantavirus is primarily associated with a single species of rodent: Hantaan virus (HTNV) with Apodemus agrarius, Seoul virus (SEOV) with Rattus norvegicus, Puumala virus (PUUV) with Clethrionomys glareolus, and PHV with M. pennsylvanicus [11]. The three Old World hantaviruses, HTNV, SEOV, and PUUV, are important causative agents of hemorrhagic fever with renal syndrome (HFRS) in Asia and Europe [12]. Strains of SEOV have been isolated from Norway rats in the United States, and infection can be very common in rats from urban locations [13-15]. However, SEOV has only rarely been associated with human disease in the United States and that was a relatively mild form of HFRS [16]. Leakey virus, which may constitute a new serotype of Hantavirus, is known from a single isolate obtained from Mus musculus in Texas [17], and Dobrava/Belgrade virus from Slovenia, Yugoslavia, isolated from Apodemus flavicollis, may be a new hantavirus on the basis of PCR-restriction fragment length polymorphism data $[18,19]$.

The outbreak of disease in the southwestern United States 
had several unusual features for a hantavirus illness. The clinical disease primarily involved respiratory rather than renal organs and function and resulted in unusually high mortality for a hantavirus-associated illness. As of 21 November 1993, 28 of 45 persons with confirmed HPS have died; the typical mortality ratio for severe HFRS is generally $<10 \%$ [20]. In addition, the geographic location of the initial outbreak was in the semiarid regions of three states, New Mexico, Arizona, and Colorado, where the known rodent reservoirs of North American hantaviruses (M. pennsylvanicus and $R$. norvegicus) are rare components of the rodent community. These observations suggested that the rodent host of the new hantavirus was different from the rodent hosts of previously described hantaviruses from North America.

Here we describe a cross-sectional survey of rodents collected from the Four Corners region of New Mexico, Arizona, and Colorado. Collections were made while active cases of HPS from this area were being reported to the Centers for Disease Control and Prevention (CDC).

\section{Materials and Methods}

Rodent collection. From June through mid-August 1993, rodents were systematically trapped at selected households in the Four Corners region of New Mexico, Arizona, and Colorado (figure 1). The most commonly trapped habitat was piñonjuniper dwarf forest at 1525-2290 m, although a few households in scrub desert habitat at lower altitudes and in Ponderosa pine habitats at higher altitudes also were visited.

Traps were placed within and around homes with confirmed human cases of HPS and at nearby homes. Additional traps were placed in locations where case-patients had spent significant periods of time, such as summer sheep camps or piñon pine groves where pine nuts were harvested. Two sizes of live traps were used: $7.6 \times 7.6 \times 12.7 \mathrm{~cm}$ traps (Sherman Trap, Tallahassee, FL) for rodents generally $<100 \mathrm{~g}$ and $12.7 \times 12.7 \times 40.6 \mathrm{~cm}$ traps (Tomahawk Trap, Tomahawk, WI) for animals as large as $1 \mathrm{~kg}$. At most sites, 100 traps ( 70 Shermans and 30 Tomahawks) were set, although in the few urban locations surveyed, fewer traps were used.

At each site, traps were set in the afternoon and collected the next morning for two consecutive nights. Rodents in traps were double-bagged and transported to a central site for processing. Animals were anesthetized with either metafane or ketaminexylazine (10:1), and blood was removed by suborbital or cardiac puncture. Animals were identified as to species and sex and weighed to the nearest gram. Weight was used as a surrogate variable for age [21], since Peromyscus species gain weight in a consistent manner during the first few months after birth [22]. Voucher specimens were collected, fixed in $10 \%$ buffered formalin, and placed in the Museum of Southwest Biology, University of New Mexico. Specimen identifications made in the field were verified for 127 chipmunks (genus Tamias) and 323 mice (genus Peromyscus) by quantitative morphologic measurements.
Special precautions were taken while handling potentially infected rodents and contaminated traps in the field. These included wearing a negative or positive air pressure respirator equipped with a high-efficiency particulate air filter, a disposable surgical gown, gloves, and booties. Traps in which a rodent was captured were disinfected with 5\% Lysol before reuse.

Organs (lung, spleen, kidneys, and liver) were aseptically removed from animals and placed in individual prelabeled cryovials. All tissues were immediately placed in liquid $\mathrm{N}_{2}$ or dry ice for storage until packed with dry ice for shipping. In the laboratory at CDC, specimens were unpacked and stored at $-70^{\circ} \mathrm{C}$ until tested.

Viral antigen production. Viral antigens for the IgG test were prepared by detergent-basic buffer extraction of infected tissue culture cells. HTNV (strain 76-118), SEOV (strain 80-39), PUUV (strain Sottkamo), and PHV (strain PHVI) were used. Vero-E6 cells infected with the virus strains were harvested at 14 days after inoculation, and cells and supernatant were separated by $10,000 \mathrm{~g}$ centrifugation at $4^{\circ} \mathrm{C}$ for $10 \mathrm{~min}$. Cells were washed once in $0.01 M$ borate-saline, $\mathrm{pH} 9.0$, and pelleted as described above. Cell pellets were resuspended in borate-saline, $\mathrm{pH} 9.0$, with $1 \%$ (vol/vol) Triton X-100 (Sigma, St. Louis) and sonicated in a chilled cup horn for $10 \mathrm{~min}$ with the device set at a $50 \%$ duty cycle. This sonicated suspension was centrifuged at $10,000 \mathrm{~g}$ for $5 \mathrm{~min}$ at $4^{\circ} \mathrm{C}$, and the supernatant was collected as the antigen. The supernatant was $\gamma$ irradiated with $2 \times 10^{6}$ rad to ensure virus inactivation. Uninfected Vero-E6 cells were similarly prepared and used as a control or comparison antigen.

ELISA. Antigens were adsorbed overnight to wells of polyvinyl chloride microtiter plates (Dynatech Laboratories, Vienna, VA) after dilution in 0.01 $M$ PBS, pH 7.4. Optimal dilutions of antigens were determined by checkerboard titration with reference sera. In this instance, antigens for HTNV, SEOV, PUUV, and PHV were diluted $1: 1000$ in PBS, and $0.1 \mathrm{~mL}$ was adsorbed to the microtiter plates overnight at $4^{\circ} \mathrm{C}$. An uninfected VeroE6 cell culture antigen also was coated to plates and was used to determine the specific binding of antibody to viral antigens. Antigen was removed from the wells by washing three times with PBS and $0.1 \%$ (vol/vol) Tween 20 (PBS-T). Sera were diluted 1:100 and fourfold through 1:6400 in 5\% skim milk in PBS-T and allowed to react with the antigen-coated wells. The sera of rats infected with SEOV and PUUV were used as positive controls, while normal mouse serum was used as the negative control for each test. Bound IgG was detected with goat antiPeromyscus leucopus and goat anti-rat (heavy- and light-chainspecific; Kirkegaard \& Perry, Gaithersburg, MD) conjugated to horseradish peroxidase. Optical densities at $410 \mathrm{~nm}$ were recorded on a microplate spectrophotometer, and the optical density (OD) of the uninfected antigen-coated well was subtracted from that of its corresponding viral antigen-coated well to yield the adjusted OD. An adjusted OD of 0.2 at each dilution was used to assign titers to each serum tested. A titer of 1:400 was considered positive for each antigen. Sera were titrated to a maximum end point of 1:6400.

ELISAs using HTNV, SEOV, PUUV, and PHV antigens were initially used to screen all sera. Because test results with antigens other than PHV indicated poor serologic cross-reactivity with 
Figure 1. Location of rodent trapping sites in Arizona, Colorado, and New Mexico.

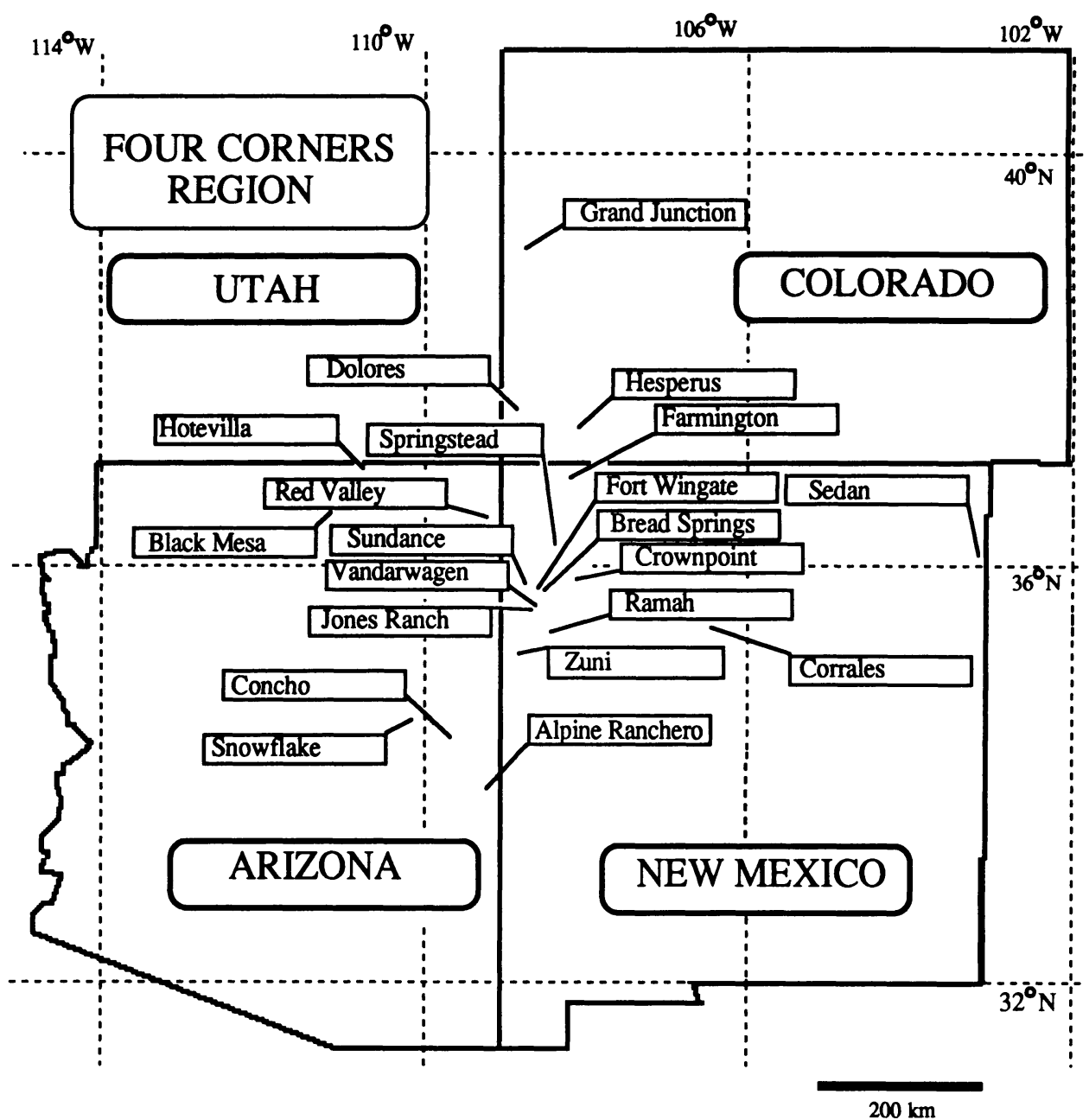

HPS virus, antigens other than PHV and SEOV were eventually dropped from the panel of tests. Testing with SEOV antigen was maintained as this serotype is known to circulate in the United States.

Rodent tissue RNA extraction, purification, and viral RNA amplification by $R T-P C R$. Because of the hazardous nature of the virus, all steps of the homogenization of rodent lung tissue samples and the total RNA extraction and purification were done in a laminar flow biocontainment hood inside an isolated biosafety level 3 containment laboratory.

RNA extractions and RT-PCR assays specific for the G2 protein-coding region of the HPS virus (and also reactive with PUUV and PHV serotypes) were done essentially as described [4, 23]. The RT-PCR assay consisted of a nested pair of reactions that used four primers designed on the basis of conserved regions identified in the HPS viral genome $M$ segment sequences [4]. The original RT-PCR assay used a plus-sense primer, 5'-CTTAAGCAATGGTGTACAACATC-3', and a minus-sense primer, 5'-CCATAACACATGGCAGAATC-3', which prime synthesis of a PCR product that is $476 \mathrm{bp}$ long. Three percent of this first reaction product was then used as template for a second or nested reaction that used a plus-sense primer, 5'-AAGGTAACACAGTSTCTGGATTC-3' ( $\mathrm{S}=\mathrm{G}$ or
C), and a minus-sense primer, 5'-GGTTATCACTTAGATCYTGAAAGG-3' $(\mathrm{Y}=\mathrm{C}$ or $\mathrm{T})$, which prime synthesis of a PCR product 172 bp long. Nested PCR primers provide additional specificity and sensitivity to the detection assay. Subsequent PCR product DNA gel electrophoresis and automated thermal cycle sequencing analysis were done essentially as described [4].

Numerous precautions and controls were used to avoid RNA template or PCR product cross-contamination. The three main steps-tissue homogenization and RNA extraction and purification, RT-PCR assay, and PCR product electrophoresis and sequence analysis-were done in separate laboratories, with the first two steps being done within laminar flow containment hoods. Disposable gloves were changed between each tissue homogenization, aerosol barrier-plugged pipette tips were used, and only a single sample tube was open at any one time throughout all procedures. Multiple blank water controls from the tissue homogenization, first-round RT-PCR, and second-round PCR steps were checked to monitor for potential cross-contamination at each stage. The nucleotide sequences of many of the PCR products were determined. Because of the extent of virus sequence diversity, most PCR products had unique sequences, confirming their unique identity. If any two samples processed 
simultaneously gave identical sequences, the result was confirmed by repeating their entire processing and analysis independently.

Data analysis. Analyses were done by using SPSS software for the personal computer [24] and Epi Info [25]. Titer values were log-transformed for comparisons of geometric mean titers (GMTs) from different ELISAs. Only animals with at least one positive ELISA for the four antigens used were included in these comparisons.

\section{Results}

Trapping results. There were 1687 rodents of 29 species captured, identified to species, and tested for hantavirus antibody (table 1). One skunk and 8 rabbits also were captured, but only the rabbits were tested. The majority of the animals were obtained from sites in New Mexico (957; 56.4\%); 569 (33.5\%) were from Arizona and 172 (10.1\%) from Colorado. Overall, Peromyscus maniculatus, the deer mouse, accounted for $47.9 \%$ of all the rodents captured, and the five species in this genus accounted for $67.8 \%$ of the animals captured. Other commonly captured rodents included chipmunks, genus Tamias, which accounted for $12.7 \%$ of all captures. All rodents, with the exception of the house mouse, $M$. musculus $(n=51)$, were species indigenous to North America.

Comparison of serologic tests. Antibodies reacting to HTNV, PUUV, PHV, or SEOV antigens were found in 342 $(20.1 \%)$ of the 1694 animals tested; 1352 (79.8\%) sera were negative to all antigens tested, $208(12.3 \%)$ were positive to a single antigen, $98(5.8 \%)$ were positive to two antigens, 33 (1.9\%) were positive to three antigens, and $3(0.2 \%)$ were positive to all the antigens used. More sera were reactive to PHV than to HTNV, PUUV, or SEOV antigens (tables 2, 3). Use of PHV antigen allowed detection of 11.0\%-13.7\% more antibody-positive animals than would have been identified with any of the other three antigens alone (table 3 ). Conversely, the other three antigens identified only $0.6 \%-1.1 \%$ of additional animals that were negative (ELISA titer, <1:400) to PHV antigen.

Comparisons of GMTs of samples for which at least one of the four ELISA tests was positive indicated that the PHV ELISA $(n=342$; GMT $=2177)$ resulted in significantly higher titers than the HTNV ELISA $(n=36$; GMT $=142)$, the PUUV ELISA $(n=235$; GMT $=146)$, or the SEOV ELISA $(n=342 ;$ GMT $=136)$ (figure $2 ; P<.001$ for all comparisons based on $t$ test for paired samples). Since the PHV ELISA detected more positive animals and resulted in higher titers, the rest of this report will consider only serologic results obtained by using PHV antigen.

Serologic results. The most commonly infected rodent was $P$. maniculatus, with an antibody prevalence of $30.4 \%$ (table 2). Evidence of infection also was found in two other species of Peromyscus (304/1150 [26.4\%] of this genus had
Table 1. Species (common names), relative proportions, and contribution of each rodent genus to total mammals collected from the Four Corners area, June-August 1993.

\begin{tabular}{|c|c|c|c|}
\hline Species & $n$ & $\begin{array}{l}\% \text { of } \\
\text { total }\end{array}$ & $\begin{array}{c}\% \text { contribution } \\
\text { by genus }\end{array}$ \\
\hline Peromyscus maniculatus (deer mouse) & 813 & 47.9 & 67.8 \\
\hline Peromyscus truei (piñon mouse) & 275 & 16.2 & \\
\hline Peromyscus boylii (brush mouse) & 51 & 3.0 & \\
\hline Peromyscus nasutus (rock mouse) & 10 & 0.6 & \\
\hline Peromyscus crinitus (canyon mouse) & 1 & 0.1 & \\
\hline Tamias dorsalis (cliff chipmunk) & 166 & 9.8 & 12.7 \\
\hline Tamias minimus (least chipmunk) & 19 & 1.1 & \\
\hline \multicolumn{4}{|l|}{ Tamias quadrivittatus (Colorado } \\
\hline chipmunk) & 30 & 1.8 & \\
\hline \multicolumn{4}{|l|}{ Ammospermophilus leucurus (whitetail } \\
\hline antelope squirrel) & 14 & 0.8 & 0.8 \\
\hline \multicolumn{4}{|l|}{ Cynomys gunnisoni (whitetail prairie } \\
\hline $\operatorname{dog})$ & 1 & 0.1 & 0.1 \\
\hline \multicolumn{4}{|l|}{ Dipodomys merriami (Merriam } \\
\hline kangaroo rat) & 4 & 0.2 & 0.7 \\
\hline Dipodomys ordii (Ord kangaroo rat) & 6 & 0.4 & \\
\hline Dipodomys species & 1 & 0.1 & \\
\hline Microtus longicaudus (longtail vole) & 2 & 0.1 & 0.5 \\
\hline Microtus mexicanus (Mexican vole) & 1 & 0.1 & \\
\hline Microtus montanus (mountain vole) & 2 & 0.1 & \\
\hline \multicolumn{4}{|l|}{ Microtus pennsylvanicus (meadow } \\
\hline vole) & 4 & 0.2 & \\
\hline Mus musculus (house mouse) & 51 & 3.0 & 3.0 \\
\hline \multicolumn{4}{|l|}{ Neotoma albigula (whitethroat } \\
\hline woodrat) & 69 & 4.1 & 6.1 \\
\hline Neotoma mexicana (Mexican woodrat) & 20 & 1.2 & \\
\hline \multicolumn{4}{|l|}{ Neotoma micropus (southern plains } \\
\hline woodrat) & 4 & 0.2 & \\
\hline Neotoma stephensi (Stephens woodrat) & 6 & 0.4 & \\
\hline Neotoma species & 2 & 0.1 & \\
\hline \multicolumn{4}{|l|}{ Onychomys leucogaster (northern } \\
\hline grasshopper mouse) & 10 & 0.6 & 0.7 \\
\hline Onychomys species & 2 & 0.1 & \\
\hline \multicolumn{4}{|l|}{ Perognathus flavus (silky pocket } \\
\hline mouse) & 5 & 0.3 & 0.4 \\
\hline Perognathus species & 2 & 0.1 & \\
\hline \multicolumn{4}{|l|}{ Reithrodontomys megalotis (western } \\
\hline harvest mouse) & 7 & 0.4 & 0.4 \\
\hline Sigmodon hispidus (hispid cotton rat) & 6 & 0.4 & 0.4 \\
\hline Spermophilus variegatus (rock squirrel) & 90 & 5.3 & 6.0 \\
\hline \multicolumn{4}{|l|}{ Spermophilus spilosoma (spotted } \\
\hline ground squirrel) & 4 & 0.2 & \\
\hline \multicolumn{4}{|l|}{ Spermophilus tridecemlineatus } \\
\hline (thirteen-lined ground squirrel) & 7 & 0.4 & \\
\hline \multicolumn{4}{|l|}{ Spermophilus lateralis (golden- } \\
\hline mantled squirrel) & 2 & 0.1 & \\
\hline Total & 1687 & 99.5 & 99.5 \\
\hline Mephitis mephitis (striped skunk)* & 1 & 0.1 & \\
\hline \multicolumn{4}{|l|}{ Sylvilagus auduboni (desert } \\
\hline cottontail)* & 8 & 0.5 & \\
\hline
\end{tabular}

* Nonrodent species. 
Table 2. Prevalence of antibody to three different hantavirus antigens in mammals collected from the Four Corners area, June-August 1993.

\begin{tabular}{|c|c|c|c|}
\hline \multirow[b]{2}{*}{ Species } & \multicolumn{3}{|c|}{ Antigen } \\
\hline & PHV & SEOV & PUUV \\
\hline Perom!scus maniculatus & $30.4(813)$ & $9.7(813)$ & $9.7(596)$ \\
\hline Peromyscus truei & $19.6(275)$ & $7.3(275)$ & $6.9(130)$ \\
\hline Peromyscus boylii & $5.9(51)$ & $2.0(51)$ & $0.0(18)$ \\
\hline Perom!scus nasutus & $0.0(10)$ & $0.0(10)$ & $0.0(1)$ \\
\hline Peromyscus crinitus & $0.0(1)$ & $0.0(1)$ & - \\
\hline Tamias dorsalis & $3.6(166)$ & $0.6(166)$ & $3.0(99)$ \\
\hline Tamias minimus & $5.3(19)$ & $0.0(19)$ & $0.0(12)$ \\
\hline Tamias quadrivittatus & $13.3(30)$ & $3.3(30)$ & $3.3(30)$ \\
\hline Ammospermophilus leucurus & $0.0(14)$ & $0.0(14)$ & $0.0(4)$ \\
\hline Cynomys gunnisoni & $0.0(1)$ & $0.0(1)$ & $0.0(1)$ \\
\hline Dipodomys merriami & $0.0(4)$ & $0.0(4)$ & $0.0(3)$ \\
\hline Dipodomys ordii & $0.0(6)$ & $0.0(6)$ & $0.0(4)$ \\
\hline Dipodomys species & $0.0(1)$ & $0.0(1)$ & $0.0(1)$ \\
\hline Microtus longicaudus & $0.0(2)$ & $0.0(2)$ & $0.0(2)$ \\
\hline Microtus mexicanus & $0.0(1)$ & $0.0(1)$ & - \\
\hline Microtus montanus & $0.0(2)$ & $0.0(2)$ & $0.0(2)$ \\
\hline Microtus pennsylvanicus & $0.0(4)$ & $0.0(4)$ & - \\
\hline Mus musculus & $3.9(51)$ & $2.0(51)$ & $9.1(22)$ \\
\hline Neotoma albigula & $2.9(69)$ & $0.0(69)$ & $0.0(24)$ \\
\hline Neotoma mexicana & $0.0(20)$ & $0.0(20)$ & $0.0(7)$ \\
\hline Neotoma micropus & $0.0(4)$ & $0.0(4)$ & $0.0(4)$ \\
\hline Neotoma stephensi & $0.0(6)$ & $0.0(6)$ & $0.0(6)$ \\
\hline Neotoma species & $0.0(2)$ & $0.0(2)$ & - \\
\hline Onvchomys leucogaster & $0.0(10)$ & $0.0(10)$ & $0.0(5)$ \\
\hline Onychomys species & $0.0(2)$ & $0.0(2)$ & - \\
\hline Perognathus flavus & $0.0(5)$ & $0.0(5)$ & $0.0(2)$ \\
\hline Perognathus species & $0.0(2)$ & $0.0(2)$ & $0.0(1)$ \\
\hline Reithrodontom!s megalotis & $28.6(7)$ & $0.0(7)$ & $33.3(3)$ \\
\hline Sigmodon hispidus & $0.0(6)$ & $0.0(6)$ & $0.0(6)$ \\
\hline Spermophilus variegatus & $1.1(90)$ & $0.0(90)$ & $0.0(40)$ \\
\hline Spermophilus spilosoma & $0.0(4)$ & $0.0(4)$ & $0.0(4)$ \\
\hline Spermophilus tridecemlineatus & $0.0(7)$ & $0.0(7)$ & $0.0(6)$ \\
\hline Spermophilus lateralis & $0.0(2)$ & $0.0(2)$ & $0.0(2)$ \\
\hline Total & $19.1(1686)$ & $6.1(1686)$ & $7.2(1034)$ \\
\hline$S_{y} y_{\text {lvilagus auduboni* }}$ & $12.5(8)$ & $12.5(8)$ & $25.0(4)$ \\
\hline
\end{tabular}

NOTE. PHV $=$ Prospect Hill virus; PUUV $=$ Puumala virus; $\mathrm{SEOV}=$ Seoul virus. Positive, titer $\geqslant 1: 400$. Values in parentheses are sample sizes.

* Nonrodent species.

antibody to PHV), although the prevalence was significantly higher in $P$. maniculatus than in Peromyscus truei $\left(19.6 \% ; \chi^{2}\right.$ $=11.86 ; P<.001)$ and in Peromyscus boylii $\left(5.9 \% ; \chi^{2}=\right.$ 14.01; $P<.001$ ). Prevalence of PHV antibody in $P$. truei was significantly higher than in $P$. boylii $\left(\chi^{2}=5.64 ; P=.02\right)$. Other species of rodent showing relatively high antibody prevalence to PHV antigen included the Colorado chipmunk Tamias quadrivittatus (13.3\% positive; overall prevalence of antibody in the genus Tamias $=5.1 \%$ ) and the western harvest mouse Reithrodontomys megalotis ( $28.6 \%$ positive), although only 7 rodents of the latter species were collected.

Titer information was limited (sera were not titrated beyond a dilution of 1:6400). Comparisons of PHV GMTs for the different mammals indicated that the 3 species of Peromyscus had among the highest titers, although no significant differences were observed among GMTs for the 11 species with at least one seropositive result (one-way analysis of variance, $F=1.65,10 d f, P=.09)$. The GMTs $\left(\log _{10} \pm \mathrm{SE}\right)$ were as follows: $P$. maniculatus, $3.36 \pm 0.04 ; P$. truei, $3.37 \pm$ 0.08; P. boylii, $3.40 \pm 0.40 ;$ Tamias dorsalis, $2.73 \pm 0.24 ; T$. quadrivittatus, $3.20 \pm 0.25$; Tamias minimus, 3.81 (single sample); M. musculus, $3.51 \pm 0.301$; Neotoma albigula, 2.60 $\pm 0.00 ; R$. megalotis, $3.20 \pm 0.000 ;$ Spermophilus variegatus, 3.20 (single sample); and Sylvilagus auduboni, $2.45 \pm 0.75$.

Geographic distribution and demographic correlates of $\mathrm{PHV}$ antibody. Animals positive for PHV were found within each state, with overall prevalences of antibody to PHV of 23.2\%, 19.2\%, and 16.5\% from Arizona, Colorado, and New Mexico, respectively $\left(\chi^{2}=10.37 ; P=.006\right)$. When only results from $P$. maniculatus were considered, nearly identical antibody prevalences from the three states were found: $32.5 \%$ positive from Arizona $(n=308), 29.1 \%$ positive from New Mexico $(n=416)$, and $29.2 \%$ positive from Colorado $(n$ $\left.=89 ; \chi^{2}=1.02 ; P=.60\right)$. Within an individual state, the prevalence of PHV antibody among study sites varied considerably (table 4). At sites where a minimum of 5 P. maniculatus were trapped, antibody prevalence varied from $9.5 \%$ to $38.6 \%$ in New Mexico, from $27.1 \%$ to $35.4 \%$ in Arizona, and from 0 to $51.3 \%$ in Colorado.

Both sexes of $P$. maniculatus showed a mass-specific pattern of antibody prevalence, suggesting that hantavirus infection was acquired in an age-dependent manner (figure 3; for males, $\chi^{2}$ for linear trend $=27.60, P<.001$; for females, $\chi^{2}$ for linear trend $\left.=7.79, P=.005\right)$. There was some indication of a similar mass-specific trend in antibody prevalence with $P$. truei; $17.2 \%$ of mice $<15$ g were positive $(n=29)$ compared with $18.8 \%$ of animals of $16-20 \mathrm{~g}(n=117), 21.4 \%$ of animals of $21-25 \mathrm{~g}(n=84)$, and $20.8 \%$ of mice $>26 \mathrm{~g}(n$ $=24)$. No distinctive pattern was observed for the genus Tamias.

Concordance between RT-PCR and serology. RT-PCR

Table 3. Pairwise comparison of ELISA results using four hantavirus antigens.

\begin{tabular}{lrrrrr}
\hline & \multicolumn{2}{c}{ Concordant results } & & \multicolumn{2}{c}{ Discordant results } \\
\cline { 2 - 3 } \cline { 6 - 6 } $\begin{array}{l}\text { Antigen } \\
\text { pair }\end{array}$ & Neg-Neg & Pos-Pos & & Pos-Neg & Neg-Pos \\
\hline PHV-SEOV & $1361(81.9)$ & $90(5.3)$ & & $233(13.7)$ & $14(0.8)$ \\
PHV-PUUV & $814(78.2)$ & $69(6.6)$ & & $152(14.6)$ & $6(0.6)$ \\
PHV-HTNV & $157(82.2)$ & $11(5.8)$ & & $21(11.0)$ & $2(1.1)$ \\
\hline
\end{tabular}

NOTE. $\mathrm{PHV}=$ Prospect Hill virus; $\mathrm{SEOV}=$ Seoul virus; $\mathrm{PUUV}=$ Puumala virus; $\mathrm{HTNV}=$ Hantaan virus; $\mathrm{Neg}=$ negative; $\mathrm{Pos}=$ positive. Data are no. (\%). 


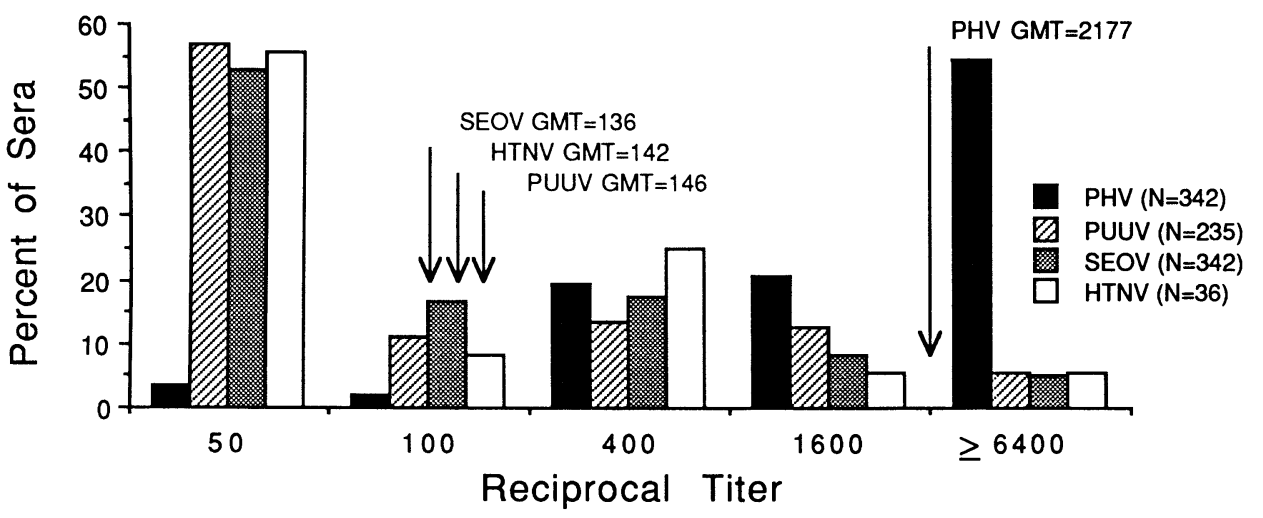

Figure 2. Distribution of rodent antibody titers to 4 hantavirus antigens as determined by ELISA. Sera were titered to maximum end point of 6400. Geometric mean titers (GMTs) for samples positive $(\geqslant 400)$ to at least one of 4 antigens are indicated. PHV $=$ Prospect Hill virus; PUUV = Puumala virus; SEOV = Seoul virus; HTNV = Hantaan virus. testing of individual animals shown to be serologically positive to PHV antigen showed a distinctive pattern of concordance between tests (table 5). Nearly all of the $P$. maniculatus found to be antibody-positive were subsequently found to have amplifiable hantavirus sequences in their tissues

Table 4. Number of animals tested and prevalence of antibody to Prospect Hill virus from locations in New Mexico, Arizona, and Colorado.

\begin{tabular}{|c|c|c|c|c|}
\hline \multirow[b]{2}{*}{ State, location } & \multicolumn{2}{|c|}{ All animals } & \multicolumn{2}{|c|}{ P. maniculatus } \\
\hline & $n$ & $\%$ positive & $n$ & $\%$ positive \\
\hline \multicolumn{5}{|l|}{ New Mexico } \\
\hline Bread Springs & 111 & 34.2 & 88 & 38.6 \\
\hline Jones Ranch & 87 & 28.7 & 41 & 36.6 \\
\hline Vandarwagen & 74 & 17.6 & 25 & 36.0 \\
\hline Fort Wingate & 23 & 17.4 & 12 & 16.7 \\
\hline Crownpoint & 194 & 17.0 & 101 & 24.8 \\
\hline Sundance & 70 & 15.7 & 19 & 36.8 \\
\hline Ramah & 200 & 12.0 & 78 & 26.9 \\
\hline Zuni & 61 & 6.6 & 15 & 26.7 \\
\hline Sedan & 54 & 5.6 & 21 & 9.5 \\
\hline Springstead & 67 & 4.5 & 16 & 12.5 \\
\hline Corrales & 13 & 0.0 & 0 & - \\
\hline Farmington & 2 & 0.0 & 0 & - \\
\hline Subtotal & 957 & 16.5 & 416 & 29.1 \\
\hline \multicolumn{5}{|l|}{ Arizona } \\
\hline Black Mesa & 194 & 30.4 & 122 & 35.2 \\
\hline Red Valley & 174 & 26.4 & 99 & 35.4 \\
\hline Concho & 87 & 14.9 & 48 & 27.1 \\
\hline Snowflake & 76 & 17.1 & 35 & 28.6 \\
\hline Alpine Ranchero & 13 & 7.7 & 0 & - \\
\hline Hotevilla & 25 & 0.0 & 4 & 0.0 \\
\hline Subtotal & 569 & 23.1 & 308 & 32.5 \\
\hline \multicolumn{5}{|l|}{ Colorado } \\
\hline Hesperus & 78 & 34.6 & 39 & 51.3 \\
\hline Grand Junction & 79 & 7.6 & 45 & 13.3 \\
\hline Dolores & 15 & 0.0 & 5 & 0.0 \\
\hline Subtotal & 172 & 19.2 & 89 & 29.2 \\
\hline Total & 1698 & 19.0 & 813 & 30.4 \\
\hline
\end{tabular}

NOTE. Total of 1698 includes 3 rodents of unidentified species.
(96.7\%). The proportions of concordant pairs for all other species were lower, ranging from 0 to $50 \%$ in genera other than Peromyscus.

Sufficient numbers of seronegative $P$. maniculatus were also tested to provide limited information on infection status in animals without antibody. Of 40 seronegative rodents, 22 (55\%) were RT-PCR-positive. One of 5 seronegative $P$. truei was RT-PCR-positive, while none of the 5 seronegative rodents not belonging to the genus Peromyscus was positive.

Nucleotide sequence analysis of virus detected in different rodent species. Sequence analysis of 37 PCR products amplified from different rodent species captured within the same Four Corners region indicated a high degree of genetic similarity (figure 4). Sequence differences as high as $\sim 7 \%$ were seen, in agreement with an earlier study of virus-infected human and rodent samples [4]. However, identical sequences also were found both within a genus for $P$. maniculatus and $P$. truei (rodents 14 and 19) and for $P$. maniculatus and $P$. boylii (rodents 2 and 1 ) and across families for $P$. maniculatus and $T$. dorsalis (rodents 21 and 22). Near identical sequences with a single nucleotide difference also were seen across diverse rodent families, as observed between $P$. maniculatus (Cricetidae) and $T$. dorsalis (Sciuridae; rodents 15 and 16, respectively) and $P$. maniculatus and M. musculus (Muridae; rodents 21 and 23).

\section{Discussion}

These data clearly implicate $P$. maniculatus as the major rodent reservoir of a newly recognized hantavirus associated with HPS in the southwestern United States. Although a homologous antigen was not available for these analyses as this virus has yet to be isolated in cell culture, serologic and genetic analyses allow definitive conclusions concerning the uniqueness of the virus and identification of its principal reservoir.

This is the first demonstration of a Cricetid rodent acting as a primary hantavirus reservoir. Both HTNV and SEOV have their origins in the Old World and infect members of 
Figure 3. Mass dependence of prevalence of antibody to Prospect Hill virus (PHV) in Peromyscus maniculatus. Sample sizes are indicated above corresponding bars.

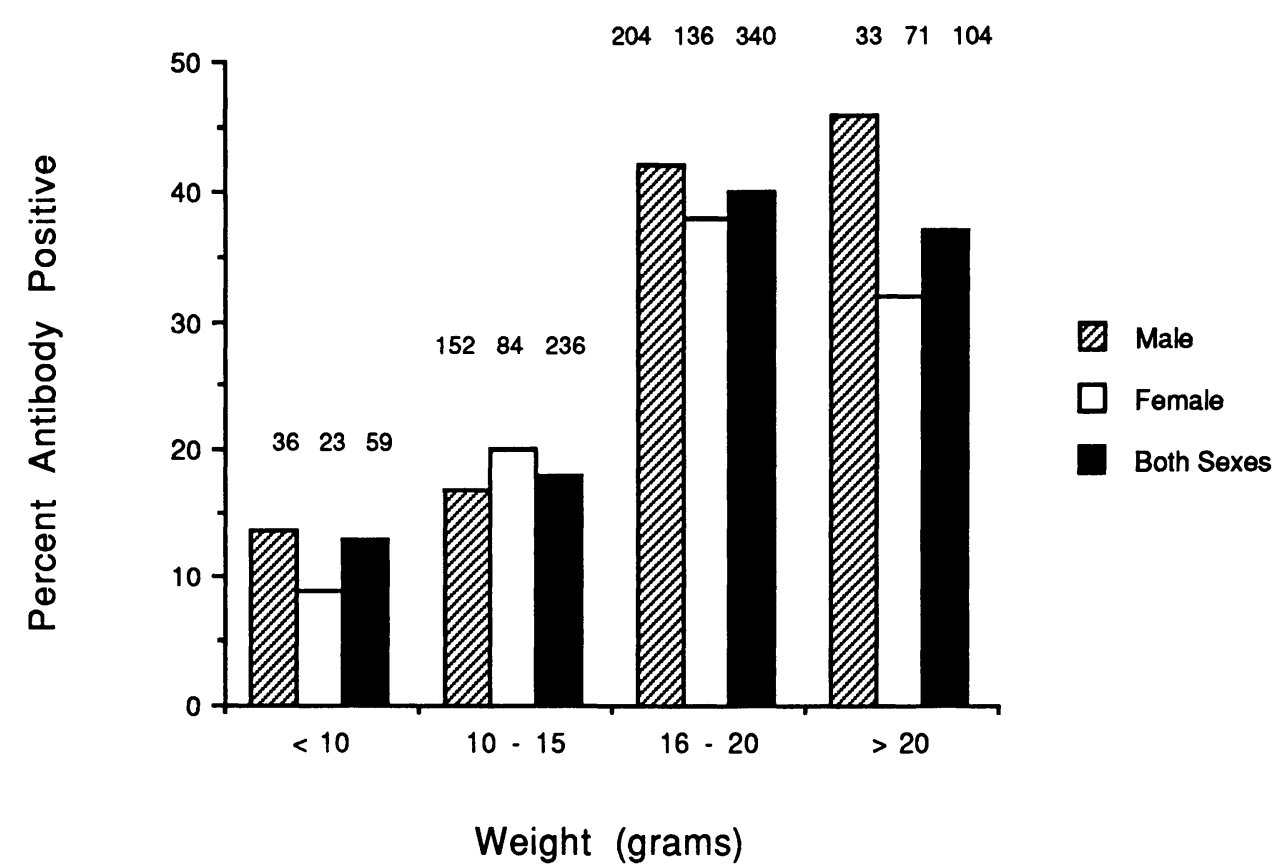

the family Muridae. Voles, family Arvicolidae, are primarily responsible for maintenance of PUUV in Europe and PHV in North America. The public health implications of $P$. maniculatus as a reservoir for a hantavirus are serious, as this species has one of the broadest geographic ranges in North America and occurs in most habitats with the exception of urban centers [26, 27]. Where $P$. maniculatus is found, it is frequently a dominant member of the rodent community and is one of the most common mammals in North America. Given the characteristics of the rodent, it is likely that the identified range of HPS in the United States will continue to expand as physicians become more aware of the syndrome.

Antibody to a hantavirus was previously reported in rodents from New Mexico and Colorado [15]. The only anti-

Table 5. Concordance of serologic testing for Prospect Hill virus (PHV) antigen and reverse transcriptase-polymerase chain reaction (RT-PCR).

\begin{tabular}{lccc}
\hline Species & $\begin{array}{c}\text { No. } \\
\text { antigen- } \\
\text { positive }\end{array}$ & $\begin{array}{c}\text { No. } \\
\text { RT-PCR } \\
\text { positive }\end{array}$ & $\begin{array}{c}\% \\
\text { concordance }\end{array}$ \\
\hline Peromyscus maniculatus & 61 & 59 & 96.7 \\
Peromyscus truei & 23 & 16 & 69.6 \\
Peromyscus boy'lii & 4 & 2 & 50.0 \\
Tamias quadrivittatus & 7 & 2 & 28.6 \\
Tamias dorsalis & 6 & 2 & 33.3 \\
Mus musculus & 2 & 1 & 50.0 \\
Reithrodontomys megalotis & 2 & 0 & 0.0 \\
Neotoma albigula & 2 & 0 & 0.0 \\
Spermophilus variegatus & 1 & 0 & 0.0 \\
Sylvilagus auduboni & 1 & 0 & 0.0 \\
\hline
\end{tabular}

gen used to identify infected rodents in previous studies was HTNV, which provided the lowest serologic titers and antibody prevalence in our study [15]. The low prevalence of antibody and low titers previously reported for $P$. maniculatus and other species (Neotoma cinerea, Neotoma mexicana) from this region (5.3\% for $P$. maniculatus; $100 \%$ of end-point indirect fluorescent antibody titers $\leq 128$ ) may, therefore, reflect the limited cross-reaction of sera with heterologous antigen rather than the actual level of infection. In addition, the failure to detect hantavirus antibodies in $P$. boylii and $P$. truei in previous studies also may be due to the poor cross-reactivity of sera to HTNV antigen. Similarly, our use of several heterologous hantavirus serotypes to identify antibody may still be underestimating the actual prevalence of infection in these rodents. Also, species-specific conjugates were not available for most rodent species tested, which also may lead to underestimates of the actual prevalence of infection. However, even with these limitations, our data show a prevalence of hantavirus infection in $P$. maniculatus similar to that found for PHV in cross-sectional surveys of $M$. pennsylvanicus. Typically, in meadow vole populations the prevalence of antibody is $15 \%-27 \%[5,8,9]$ (Burek $\mathrm{K}$, LeDuc $\mathrm{J}$, unpublished data).

The pattern of hantavirus infection in $P$. maniculatus is consistent with the characteristics previously described for unique hantavirus serotypes and their respective primary rodent hosts. First, the primary rodent reservoir is a common species in the region or habitat examined. In the Four Corners region, $P$. maniculatus accounted for $48 \%$ of the rodent community (table 1). Second, the prevalence of infection as measured by antibody is highest in the primary reservoir (30\% in P. maniculatus), although infection of other 


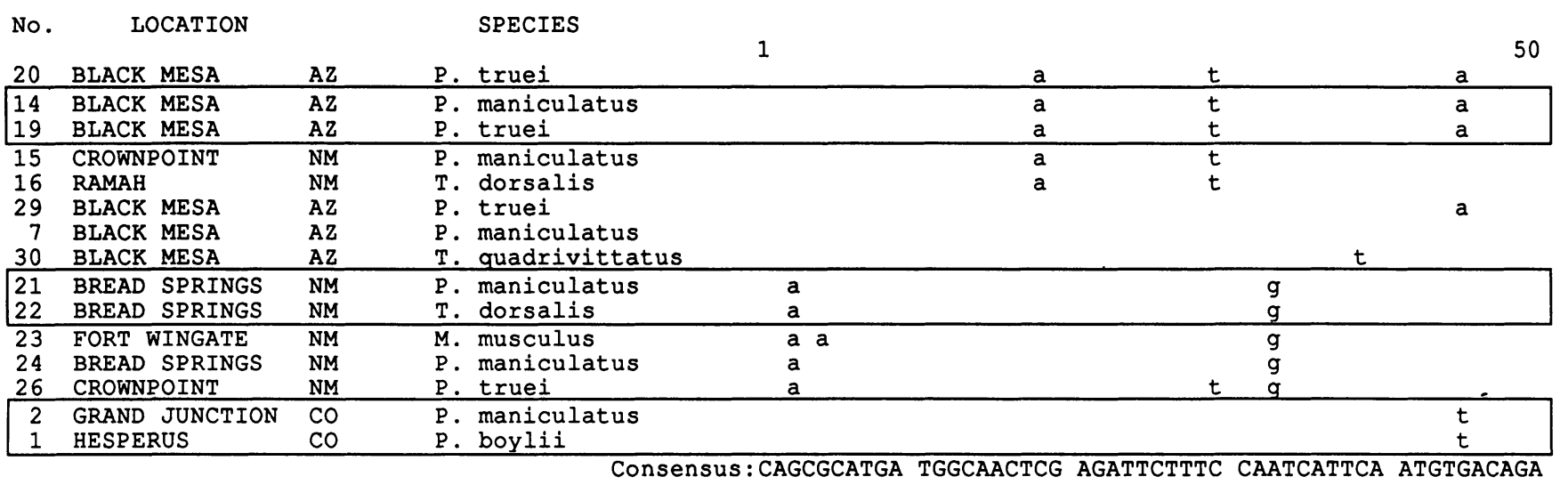

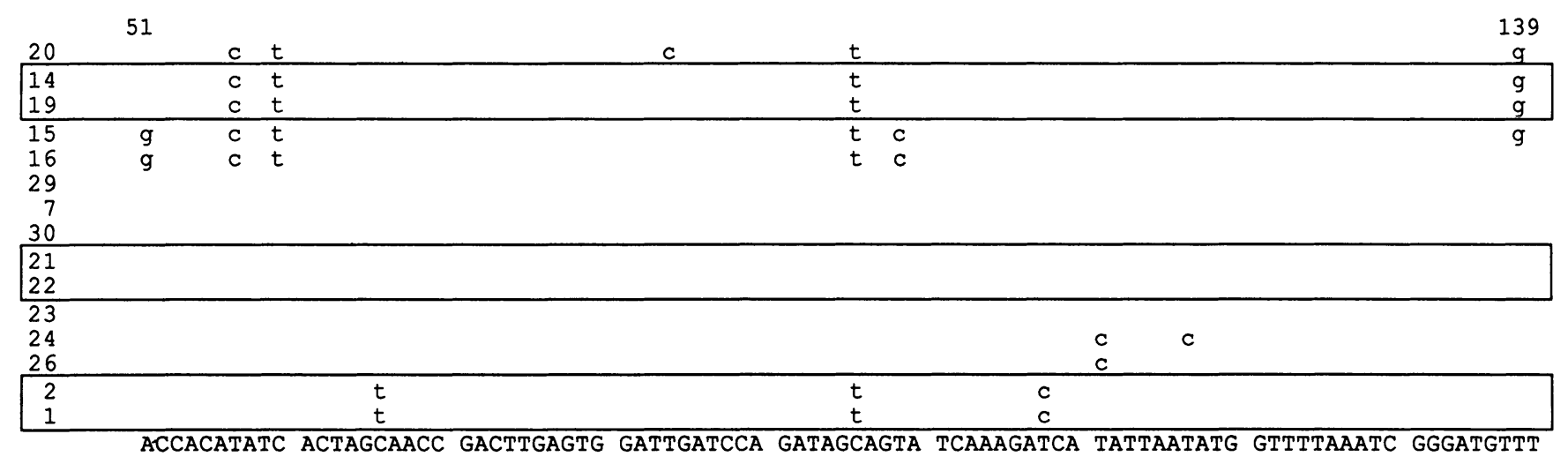

Figure 4. Sequence analysis of 139-bp region of $\mathrm{G} 2$ gene of hantavirus pulmonary syndrome virus obtained from different rodent species in the Four Corners region. Included are sequences for rodents 1, 2, 7, and 14 as published previously [4]. Boxed sequences are identical. Up to $7 \%$ sequence difference compared to consensus sequence was observed.

sympatric species was found in the Southwest (table 2). Hantavirus infections in secondary hosts are well documented [8, $9,28,29]$. Third, there is evidence of virus persistence in the primary reservoir species, as indicated by our ability to consistently amplify hantavirus sequences from serologically positive $P$. maniculatus, while other seropositive rodents (although there were fewer of them) were less frequently or rarely RT-PCR-positive (table 5). The ability to amplify hantavirus sequences from seropositive rodents has been previously demonstrated for SEOV and $R$. norvegicus [30] and was interpreted as the result of a persisting infection in the presence of a vigorous antibody response. This virus-host relationship has become a hallmark of specific hantavirus infections in their primary rodent reservoirs [11]. Finally, as in SEOV infections of Norway rats and PHV infections of $M$. pennsylvanicus, there is a clear mass-dependent association of antibody, indicating age-dependent infection $[9,21]$. $P$. maniculatus achieve a body mass of $10 \mathrm{~g}$ at $\sim 3-4$ weeks of age and adult weights at $\sim 8-10$ weeks; puberty begins at $\sim 4-6$ weeks [22]. As with other hantavirus infections, the mass-specific pattern of antibody presumably indicates horizontal transmission of virus by age-dependent mechanisms or the cumulative results of such transmission.
Genetic analyses were used to address several unresolved issues. The viral sequences identified from all the RT-PCRpositive rodents were genetically similar and belong to the new hantavirus group previously described [4]. No evidence was found for distinct virus variants specifically associated with infection of different rodent species. The genetic data suggest that virus is not being independently maintained in different species but that occasionally virus from the predominant rodent reservoir, $P$. maniculatus, spills over to other species. The high prevalence of antibody and the indication from RT-PCR amplification of hantavirus sequences from seronegative $P$. maniculatus that more rodents are infected than can be detected by serology alone point to a very high prevalence of infection in this species. However, it is unclear at this time whether these RT-PCR-positive, seronegative mice reflect the higher sensitivity of the PCR method compared with serologic testing or were tested during early acute infection before antibodies developed.

Specific hantavirus-primary rodent reservoir pairs may have existed for extensive periods, with possible coevolution of rodent host and virus parasite. The data presented here support such a hypothesis. First, this new hantavirus is primarily associated with $P$. maniculatus, an indigenous North 
American species, and is genetically most closely related to PHV, which has $M$. pennsylvanicus (another rodent indigenous to North America) as its primary rodent reservoir. Both North American hantaviruses are more distantly related to the HTNV and SEOV associated with Eurasian rodent hosts [4]. Second, genetic diversity among HPS viruses, sampled during a short time scale from the limited geographic range of the Four Corners region, is substantial, with sequence divergence as much as $7 \%$. If HPS virus was newly emerged and causing an epizootic in rodent populations in the Southwest, then greater genetic homogeneity would be expected during the short period and in the limited geographic area sampled. These data are more consistent with the scenario of a well-established virus-rodent relationship with virus genetic diversity accumulating in semiisolated rodent populations over extensive periods.

The natural history of HPS virus in $P$. maniculatus has yet to be elucidated in the field or laboratory. Once virus is isolated in cell culture, the course of infection can be followed to determine if HPS virus produces the same sort of persistent infection, with chronic virus shedding, as does HTNV in A. agrarius [31], PUUV in C. glareolus [32, 33], and SEOV in $R$. norvegicus [34]. Long-term field studies of the incidence of HPS virus in $P$. maniculatus populations, as related to rodent population density and environmental and seasonal influences, will be necessary to identify factors involved in the spillover of infection to humans. Specific risk factors for human hantavirus infection and environmental correlates of the level of rodent infestation and prevalence of infection will be addressed in the future. Recommendations for rodent population reduction and habitat modification have been issued [26] as a first step in reducing human risk of exposure to hantaviruses maintained in $P$. maniculatus populations. Until more is learned about the HPS virus, the immunobiology of the disease it causes, and the need and prospects for a vaccine, reducing human contact with rodent reservoirs will be the primary means of minimizing risk.

\section{Note Added in Proof}

Since the submission of this report, a hantavirus has been isolated in cell culture from lung tissue of infected Peromyscus maniculatus. This new virus has been named Muerto Canyon virus and is synonymous with the designation hantavirus pulmonary syndrome (HPS) virus used in this report.

\section{Acknowledgments}

Assistance in environmental assessments and rodent trapping was provided by Ted Brown and Pam Reynolds (New Mexico Department of Health); John Doll, Craig Levy, and Michael
Fink (Arizona Department of Health); Ted Davis (Colorado Department of Health); Herman Shorty (Navajo Nation); Pat Bohan, Sue Harvey, Leonard Freeland, Ralph Fulgham, Robert Bialas, Doris Lynch, Duane Kilgus, David Tibbs, Raymond Charleston, Amanda Anderson, Angie Maloney, James Jackson, Howard Yazzie, Larry Hart, Larry Cseh, Minnie Yazzie, and Bennie Joe (Indian Health Service); and Louisa Chapman (CDC). Robert Dickerman (University of New Mexico) assisted in the collection of museum specimens. John O'Conner provided valuable editorial assistance and Tony Sanchez helped draft artwork. Laboratory technical assistance was provided by Marty Monroe and Sam Trappier.

\section{References}

1. Centers for Disease Control and Prevention. Update: hantavirus infection-southwestern United States. MMWR 1993;42:495-6.

2. Centers for Disease Control and Prevention. Update: outbreak of hantavirus infection-southwestern United States. MMWR 1993; 42:441-3

3. Centers for Disease Control and Prevention. Update: outbreak of hantavirus infection-southwestern United States. MMWR 1993; 42:477-9.

4. Nichol ST, Spiropoulou CF, Morzunov S, et al. Genetic identification of a hantavirus associated with an outbreak of acute respiratory illness. Science 1993;262:914-7.

5. Lee PW, Amyx HL, Yanagihara R, Gajdusek DC, Goldgaber D, Gibbs CJ Jr. Partial characterization of Prospect Hill virus isolated from meadow voles in the United States. J Infect Dis 1985;152:826-9.

6. Yanagihara R. Hantavirus infection in the United States: epizootiology and epidemiology. Rev Infect Dis 1990;12:449-57.

7. Yanagihara R, Gajdusek DC, Gibbs CJ Jr, Traub R. Prospect Hill virus: serological evidence for infection in mammalogists. N Engl $J$ Med 1984;310:1325-6.

8. Yanagihara R, Daum CA, Lee PW, et al. Serological survey of Prospect Hill virus infection in indigenous wild rodents in the USA. Trans $\mathbf{R}$ Soc Trop Med Hyg 1987;81:42-5.

9. Childs JE, Glass GE, Korch GW, LeDuc JW. The ecology and epizootiology of hantaviral infections in small mammal communities of Baltimore: a review and synthesis. Bull Soc Vector Ecol 1988;13: 113-22.

10. Korch GW, Childs JE, Glass GE, Rossi CA, LeDuc JW. Serologic evidence of hantaviral infections within small mammal communities of Baltimore, Maryland: spatial and temporal patterns and host range. Am J Trop Med Hyg 1989;41:230-40.

11. LeDuc JW. Epidemiology of Hantaan and related viruses. Lab Anim Sci 1987;37:413-8.

12. Lee HW. World Health Organization (WHO) collaborating center for virus reference and research. In: Lee HW, Dalrymple JM, eds. Manual of hemorrhagic fever with renal syndrome. Seoul, Korea: Korea University, 1989:11-8.

13. Childs JE, Korch GW, Glass GE, LeDuc JW, Shah KV. Epizootiology of hantavirus infections in Baltimore; isolation of a virus from Norway rats, and characteristics of infected rat populations. Am J Epidemiol 1987;126:55-68.

14. LeDuc JW, Smith GA, Johnson KM. Hantaan-like viruses from domestic rats captured in the United States. Am J Trop Med Hyg 1984;33: 992-8.

15. Tsai TF, Bauer SP, Sasso DR, et al. Serological and virological evidence of a Hantaan virus-related enzootic in the United States. J Infect Dis $1985 ; 152: 126-36$. 
16. Glass GE, Watson AJ, LeDuc JW, Childs JE. Domestic cases of hemorrhagic fever with renal syndrome in the United States. Nephron (in press).

17. Baek LJ, Yanagihara R, Gibbs CJ Jr, Miyazaki M, Gajdusek DC. Leakey virus: a new hantavirus isolated from Mus musculus in the United States. J Gen Virol 1988;69:3129-32.

18. Avsic-Zupanc T, Xiao SY, Stojanovic R, Gligic A, van der Groen G, LeDuc JW. Characterization of Dobrava virus: a hantavirus from Slovenia. Yugoslavia. J Med Virol 1992;38:132-7.

19. Gligic A. Dimkovic N, Xiao SY, et al. Belgrade virus: a new hantavirus causing severe hemorrhagic fever with renal syndrome in Yugoslavia. J Infect Dis 1992;166:113-20.

20. Chun CH, Lähdevirta J, Lee HW. Clinical manifestations of HFRS. In: Lee HW, Dalrymple JM, eds. Manual of hemorrhagic fever with renal syndrome. Seoul, Korea: Korea University, 1989:19-38.

21. Childs JE, Korch GW, Smith GA, Terry AD, LeDuc JW. Geographical distribution and age-related prevalence of Hantaan-like virus in rat populations of Baltimore, Maryland, USA. Am J Trop Med Hyg 1985;34:385-7.

22. Layne JN, Ontogeny. In: King JA, ed. Biology of Peromyscus (Rodentia). Lawrence, KS: Special Publications of the American Society of Mammalogists, 1968:148-253.

23. Rodriguez LL, Letchworth GJ, Spiropoulou CF, Nichol ST. Rapid detection of vesicular stomatitis virus New Jersey serotype in clinical samples by using polymerase chain reaction. J Clin Microbiol 1993;31:2016-20.

24. Norusis MJ. Statistics guide. SPSS/PC+ statistics 4.0 for the IBM/PC/ XT/AT/ and PS/2. Chicago: SPSS Inc, 1990:1-219.

25. Dean AG, Dean JA, Burton AH, Dicker RC. Epi Info, version 5: a word processing, database, and statistics program for epidemiology on microcomputers. Atlanta: Centers for Disease Control, 1990:1-384.
26. Centers for Disease Control and Prevention. Hantavirus infection-southwestern United States: interim recommendations for risk reduction. MMWR 1993;42(RR-11):13.

27. Baker RH. Habitats and distribution. In: King JA, ed. Biology of Peromyscus (Rodentia). Lawrence, KS: Special Publications of the American Society of Mammalogists, 1968:98-126.

28. Gavrilovskaya IN, Apekina NS, Myasnikov YA, et al. Features of circulation of hemorrhagic fever with renal syndrome (HFRS) virus among small mammals in the European USSR. Arch Virol 1983;75:313-6.

29. Sommer AI, Traavek T, Mehl R, Berdal BP, Dalrymple JM. Reservoir animals for nephropathia epidemica in Norway: indications of a major role for the bank vole ( $C$. glareolus) in comparison with the woodmouse (A. svlvaticus). J Hyg (Camb) 1985;94:123-7.

30. Arthur RR, Lofts RS, Gomez J, Glass GE, LeDuc JW, Childs JE. Grouping of hantaviruses by small (S) genome segment polymerase chain reaction and amplification of viral RNA from wild-caught rats. Am J Trop Med Hyg 1992;47:210-24.

31. Lee HW, Lee PW, Baek LJ, Song CK, Seong IW. Intraspecific transmission of Hantaan virus, etiologic agent of Korean hemorrhagic fever, in the rodent Apodemus agrarius. Am J Trop Med Hyg 1981; 30:1106-12.

32. Yanagihara R. Amyx HL, Gajdusek DC. Experimental infection with Puumala virus, the etiologic agent of nephropathia epidemica. in bank voles (Clethrionomys glareolus). J Virol 1985;55:34-8.

33. Bogdanova SB, Gavrilovskaya IN, Boyko VA, et al. Persistent infection caused by hemorrhagic fever with renal syndrome in red mice (Clethrionomys glareolus), natural hosts for the virus [in Russian, translated by SCITRAN]. Mikrobiol Zh 1987;49:99-106.

34. Tanishita O, Takahashi Y, Okuno Y, et al. Persistent infection of rats with haemorrhagic fever with renal syndrome virus and their antibody responses. J Gen Virol 1986;67:2819-24. 